\title{
ANALISI ZAT GIZI MIKRO DAN TINGGI BADAN IBU BALITA TERHADAP KEJADIAN STUNTING DI DAERAH GAMBUT DAN ALIRAN SUNGAI
}

\section{Analysis Of Micro Nutritional And Mother Height To Event Of Stunting In Peatland And River Flow Area}

\section{Dahliansyah ${ }^{*}$ \\ *IPoltekkes Kemenkes Pontianak I, Pontianak, Kalimantan Barat, Indonesia}

*email: dahlian_syah_gz@yahoo.co.id

\begin{abstract}
Abstrak
Masalah stunting dapat dipengaruhi oleh kualitas dan kuantitas gizi baik mikro maupun makro yang tidak adekuat dan kronis khususnya sejak masih janin sampai usia 2 tahun, serta anak yang sakit-sakitan. Kejadian stunting juga dapat disebabkan faktor genetik (keturunan) diman pesan genetik yang diterima anak dari orang tua yang tersimpan dalam Deocsiribose Nucleic Acid (DNA) akan menampilkan bentuk fisik dan potensi bayi, walaupun faktor ini bukanlah satu-satunya faktor yang menentukan tumbuh kembang bayi. Penelitian ini bertujuan mengetahui status zat gizi mikro, dan eksklusif, tinggi badan ibu dengan kejadian stunting di daerah gambut dan aliran sungai. Desain penelitian ini adalah rancangan analitik dengan desaign case control antara daerah gambut dengan aliran sungai, dengan pendekatan retrospektif dari faktor-faktor risiko stunting. Jumlah sampel 100 balita denga 50 kasus dan 50 konrol. Analisis statistik yang akan dilakukan meliputi analisis univariabel, bivariabel dengan Regresi Logistik. Hasil penelitian didapat ada hubungan signifikan $(p<0,05)$ antara zat gizi mikro dengan kejadian stunting di daerah gambut dan bantaran sungai. Balita daerah gambut dan bantaran sungai yang mengalami asupan zat gizi mikro rendah memiliki peluang 0,24 kali dan 5,8 kali mengalami stunting. Tidak ada hubungan signifikan antara tinggi badan ibu (TB) dengan kejadian stunting baik daerah gambut maupun daerah aliran sungai $(p>0,05)$. Namun ibu balita yang TB $<$ I50 cm berpeluang I,7 kali pada daerah gambut dan 0,54 kali daerah aliran sungai untuk melahirkan balita stunting. Kesimpulan. Ada hubungan bermakna status zat gizi mikro, serta tidak ada hubungan bermakna status Tinggi Badan lbu dengan kejadian stunting daerah gambut dan aliran sungai.
\end{abstract}

Kata Kunci:

Zat Gizi Mikro

Tinggi Badan lbu

Stunting

\section{Keywords:}

Micro Nutrients

Mother's Height

Stunting

\begin{abstract}
The issue of hindering can be impacted by insufficient and incessant quality and amount, both small scale and large scale, particularly from the hatchling to the age of 2 a long time, as well as wiped out children. The frequency of hindering can too be caused by hereditary variables (heredity) where the hereditary message gotten by children from guardians put away in Deoxyribose Nucleic Corrosive (DNA) will show the physical shape and potential of the child, in spite of the fact that this figure is the as it were figure that decides the baby's development and advancement. . This think about points to decide the micronutrient status, and only, the stature of the mother with the rate of hindering in peat and waterway bowl regions. The plan of this think about is an expository plan with a case control plan between peat zones and waterway streams, with a review approach to hindering chance variables. The number of tests is 100 children beneath five with 50 cases and 50 controls. Factual examination to be carried out incorporates univariable, bivariable examination with Calculated Relapse. The comes about appeared that there was a critical relationship $(p<0.05)$ between micronutrients and hindering in peat ranges and riverbanks. Little children in peat and riverbank zones who encounter micronutrient admissions have 0.24 times and 5.8 times the chance of encountering hindering. There was no critical relationship between maternal stature (TB) and the rate of hindering in both peat and watershed ranges ( $p>0.05$ ). In any case, moms of little children with $T B<$ $150 \mathrm{~cm}$ were cut 1.7 times in peat zones and 0.54 times in watersheds to grant birth to hindering little children. Conclusion. There's a noteworthy relationship between micronutrient status, and no noteworthy relationship between maternal stature status and hindering in peat ranges and waterway flows.
\end{abstract}




\section{PENDAHULUAN}

Stunting menjadi perhatian global sehingga dimasukkan sebagai indikator target dalam Sustainable Development Goal (SDG) dimana diharapkan tahun 2030 tidak ada kelaparan dan malnutrisi (Banerjee and Dwivedi, 2020). Badan kesehatan dunia World Health Organization (WHO) menargetkan penurunan stunting sebesar $40 \%$ bagi anak di bawah 5 tahun pada tahun 2025 (WHO, 20I4). Angka kejadian stunting nasional dikalangan balita sebesar 37,2\% dan 30,8\% berturut-turut pada tahun 2013 dan 2018 (Kementerian Kesehatan RI, 2018). Sedangkan angka stunting Provinsi Kalimantan Barat berdasarkan data pemantauan status gizi tahun 2016 sebesar 34,9\% dan meningkat pada tahun 2017 menjadi 36,5. Balita stunting mengalami gangguan pertumbuhan linier dan berdampak ketidak sesuaian antara tinggi badan dengan umur (Fatimah and Wirjatmadi, 20I8). Stunting ditandai dengan indikator TB/U dengan nilai $Z$ skor < - 2 (Kemenkes RI, 2020).

Penyebab yang secara langsung mempengaruhi kejadian stunting yaitu genetik, asupan zat gizi dan penyakit infeksi (Sulistyaningsih, Panunggal and Murbawani, 2018). Tidak adekuatnya asupan gizi yang dikonsumsi dan berlangsung lama, dimulai saat bayi di dalam kandungan, diperberat dengan berbgai penyakit penyerta yang dialami ibu merupakan faktor memperberat terjadinya stunting (Halim, Warouw and Manoppo, 2018). Asupan zat gizi makro dan dan mikro dapat pula menyebabkan gangguan pertumbuhan fisik, termasuk tinggi badan ( Welasasih dan Wirjatmadi, 20I2). Kadar zinc yang rendah merupakan faktor risiko yang paling mempengaruhi stunting pada anak usia 2-5 tahun (Bening, Margawati and Rosidi, 20I7).

Kejadian stunting juga dapat disebabkan faktor genetik (keturunan) diman pesan genetik yang diterima anak dari orang tua yang tersimpan dalam Deocsiribose Nucleic Acid (DNA) akan menampilkan bentuk fisik dan potensi bayi, walaupun faktor ini bukanlah satu-satunya faktor yang menentukan tumbuh kembang bayi (Fikawati, 2009). Penelitian Toliu et al., (2018) menyebutkan bahwa terdapat hubungan tinggi badan ibu dengan kejadian stunting pada anak usia 24-59 bulan. Menurut Zottarelli (2014) bahwa seorang ibu memiliki tinggi badan $<150 \mathrm{~cm}$ beresiko memiliki anak stunting dibandingkan dengan ibu yang memiliki tinggi badan $>150 \mathrm{~cm}$. Stunting merupakan proses siklus karena perempuan yang dulunya stunting pada masa kanakkanak cenderung memiliki keturunan yang stunting (Prendergast and Humphrey, 20I4). IMT ibu berhubungan dengan ukuran janin yang lebih kecil pada awal kehamilan dan memperpanjang durasi kehamilan (Thagaard et al., 2018)

Menurut hasil evaluasi program Kemeterian Kesehatan stunting disebabkan praktek pengasuhan yang kurang baik, masih terbatasnya layanan kesehatan termasuk layanan ANC-Ante Natal Care (pelayanan kesehatan untuk ibu selama masa kehamilan) Post Natal Care dan pembelajaran dini yang berkualitas, masih kurangnya akses rumah tangga/keluarga ke makanan bergizi, dan kurangnya akses ke air bersih dan sanitasi. Pemerintah Indonesia berkomitmen untuk menurunkan prevalensi stunting dengan fokus intervensi pada 1.000 hari pertama kehidupan (I000 HPK), dengan memenuhi kebutuhan dasar sejak ibu hamil dan anak usia 0-2 tahun. Upaya tersebut harus didukung dengan efektifitas program yang telah dilaksanakan termasuk pemberian zat gizi mikro dalam penanganan stunting. Melalui penelitian ini akan dapat memberikan gambaran asupan zat gizi miro terutama didaerah gambut dan aliran sungai.

\section{METODOLOGI}

\section{Jenis Penelitian}

Jenis penelitian ini adalah rancangan analitik dengan desaign case control antara daerah gambut dengan aliran sungai kapuas, dengan pendekatan retrospektif dari faktor-faktor risiko stunting.

\section{Lokasi dan Waktu Penelitian}

Penelitian ini dilaksanakan di wilayah Kelurahan Tanjung Hilir dan Kelurahan Siantan Hulu Kota Kota Pontianak 


\section{Populasi dan Sampel}

Populasi dalam penelitian ini adalah balita usia 24-59 bulan di wilayah Kelurahan Tanjung Hilir dan Siantan Hulu Kota Pontianak. Sampel dalam penelitian ini adalah, 50 balita kelompok kasus dan 50 balita kelompok kontrol. Teknik pengambilan sampel menggunakan metode simple random sampling, dengan kriteria sampel yaitu balita usia 24 - 59 bulan yang memiliki KMS dan memiliki catatan lengkap riwayat Tinggi Badan ibu.

\section{Pengumpulan Data}

Pengumpulan data dilakukan dimulai dari data zat gizi mikro diperoleh dengan wawawancara menggunakan form recall 24 jam, dan Tinggi Badan Ibu diperoleh dengan wawawancara menggunakan kuesioner dan data status gizi balita (stunting) diperoleh dengan cara pengukuran antropometri.

\section{Pengolahan dan Analisis Data}

software analisa data. Uji statisktik menggunakan Regresi Logistik. Analisis berupa univariat untuk melihat proporsi dan bivariat untuk menguji perbedaan antara variabel inependen dan dependen.

\section{HASIL DAN PEMBAHASAN}

\section{HASIL}

\section{Karakteristik Umum Responden}

Tabel I. Distribusi Frekwensi Karakteristik Balita Usia 24-59 bulan daerah gambut dan aliran sungai Tahun 2020

\begin{tabular}{|c|c|c|c|c|}
\hline \multirow{2}{*}{ Variabel } & \multicolumn{2}{|c|}{ Gambut } & \multicolumn{2}{|c|}{$\begin{array}{c}\text { Bantaran } \\
\text { Sungai }\end{array}$} \\
\hline & $\mathbf{n}$ & $\%$ & n & $\%$ \\
\hline \multicolumn{5}{|l|}{ Jenis Kelamin } \\
\hline Laki-laki & 24 & 48 & 23 & 46 \\
\hline Perempuan & 26 & 52 & 27 & 54 \\
\hline \multicolumn{5}{|l|}{ Umur balita } \\
\hline 6-1 I bln & l & 2 & I & 2 \\
\hline 12-47 bln (I-3thn) & 34 & 68 & 29 & 58 \\
\hline $48-72$ bln (4-6 thn) & 15 & 30 & 20 & 40 \\
\hline \multicolumn{5}{|l|}{ Panjang Badan Lahir } \\
\hline$<48 \mathrm{~cm}$ & I I & 22 & 14 & 28 \\
\hline$\geq 2500 \mathrm{gr}$ & 39 & 78 & 36 & 72 \\
\hline \multicolumn{5}{|l|}{ Zat Gizi Mikro } \\
\hline Sesuai AKG ( $\geq 70 \%)$ & 2 & 4 & 50 & 100 \\
\hline Tdk Sesuai AKG (<70\%) & 48 & 96 & 0 & 0 \\
\hline \multicolumn{5}{|l|}{ Status Gizi } \\
\hline Stunting & 22 & 44 & 22 & 44 \\
\hline Normal & 28 & 56 & 28 & 56 \\
\hline
\end{tabular}

\begin{tabular}{lllll}
\hline Jumlah & 50 & 100 & 50 & 100
\end{tabular} Berdasarkan Tabel I terlihat bahwa jenis kelamin perempuan lebih banyak dibandingkan laki-laki, baik daerah gambut maupun bantaran sungai yaitu $52 \%$ dan 54\%. Umur subjek penelitian, lebih banyak kelopok umur 12-47 bulan baik daerah gambut maupun bantaran sungai yaitu sebesar $68 \%$ dan $58 \%$. Lebih banyak, subjek penelitian ketika lahir memiliki panjang badan $>48 \mathrm{~cm}$ baik daerah gambut maupun daerah aliran sungai. Balita lebih banyak mengalami defisit atau kekurangan zat gizi mikro jika dibandingkan dengan Angka Kecukupan Gizi (AKG). Sedangkan status gizi lebih banyak status gizi normal dibandingkan dengan stunting baik daerah gambut maupun daerah aliran sungai

Tabel 2. Distribusi Frekwensi Karakteristik lbu Balita Usia 24-59 bulan Daerah Gambut dan Aliran Sungai Tahun 2020

\begin{tabular}{|c|c|c|c|c|}
\hline \multirow{2}{*}{ Variabel } & \multicolumn{2}{|c|}{ Gambut } & \multicolumn{2}{|c|}{$\begin{array}{c}\text { Bantaran } \\
\text { Sungai }\end{array}$} \\
\hline & $\mathbf{n}$ & $\%$ & $\mathbf{n}$ & $\%$ \\
\hline \multicolumn{5}{|l|}{ Pendidikan Ibu } \\
\hline Tamat SD & 13 & 26 & 24 & 48 \\
\hline Tamat SLTP/Sederajat & II & 22 & 16 & 32 \\
\hline Tamat SLTA/Sederajat & 22 & 44 & 10 & 20 \\
\hline Perguruan Tinggi & 4 & 8 & 0 & 0 \\
\hline \multicolumn{5}{|l|}{ TB Ibu } \\
\hline$<150 \mathrm{~cm}$ & 9 & 18 & 5 & 10 \\
\hline$>150 \mathrm{~cm}$ & 41 & 82 & 45 & 90 \\
\hline \multicolumn{5}{|l|}{ Usia Kehamilan } \\
\hline$<9$ Bulan & 7 & 14 & 5 & 10 \\
\hline$\geq 9$ bulan & 43 & 86 & 45 & 90 \\
\hline Jumlah & 50 & 100 & 50 & 100 \\
\hline
\end{tabular}

Berdasarkan Tabel 2 terlihat bahwa, pendidikan ibu, pada daerah gambut lebih banyak tamatan SMA/Sederajat sedangkan daerah bantaran sungai lebih banyak tamatan SD/Sederajat. Tinggi Badan (TB) Ibu menunjukkan lebih banyak ibu tinggi badan $<150 \mathrm{~cm}$ baik daerah gambut maupun daerah bantaran sungai. Sedangkan usia Kehamilan didapat bahwa lebih banyak usia kehamilan diatas 9 bulan baik daerah gambut maupun bantaran sungai. 


\section{Analisi Bivariat}

Tabel 3. Hubungan Zat Gizi Mikro dan TB lbu dengan Kejadian Stunting Daerah Gambut dan Aliran Sungai Tahun 2020

\begin{tabular}{|c|c|c|c|c|c|c|c|c|c|c|c|c|c|c|}
\hline \multirow{3}{*}{ Variabel } & \multicolumn{7}{|c|}{ Daerah Gambut } & \multicolumn{7}{|c|}{ Aliran Sungai } \\
\hline & \multicolumn{2}{|c|}{ Stunting } & \multicolumn{2}{|c|}{ Normal } & \multicolumn{2}{|c|}{ Jumlah } & \multirow[t]{2}{*}{$p$} & \multicolumn{2}{|c|}{ Stunting } & \multicolumn{2}{|c|}{ Normal } & \multicolumn{2}{|c|}{ Jumlah } & \multirow[t]{2}{*}{$p$} \\
\hline & $\mathrm{n}$ & $\%$ & $n$ & $\%$ & $n$ & $\%$ & & $\mathrm{n}$ & $\%$ & $\mathrm{n}$ & $\%$ & $n$ & $\%$ & \\
\hline Zat Gizi Mikro & & & & & & & & & & & & & & \\
\hline Sesuai AKG & 10 & 52,6 & 9 & 47,4 & 19 & 100 & 0,029 & 1 & 7,1 & 13 & 92,9 & 14 & 1000 & 0,039 \\
\hline $\begin{array}{l}\text { Tidak Sesuai AKG } \\
\text { TB lbu }\end{array}$ & 7 & 22,6 & 24 & 77,4 & 31 & 100 & & 14 & 38,9 & 22 & 61,6 & 36 & 100 & \\
\hline$\geq 150 \mathrm{~cm}$ & 13 & 31,7 & 28 & 68,3 & 41 & 100 & 0,467 & 13 & 28,9 & 32 & 71,1 & 45 & 1000 & 0,629 \\
\hline$<150 \mathrm{~cm}$ & 4 & 44,4 & 5 & 55,6 & 9 & 100 & & 2 & 40 & 3 & 60 & 5 & 100 & \\
\hline
\end{tabular}

a. Hubungan antara zat gizi mikro dengan kejadian stunting

Berdasarkan Tabel 3 menunjukan bahwa pada daerah gambut dan aliran sungai subjek penelitian lebih banyak mendapatkan zat gizi mikro tidak sesuai AKG, mengalamai status gizi normal 77,4\% dan 61,6\%. Hasil uji chi square menunjukan bahwa ada hubungan yang signifikan $(P=<0,05)$ antara zat gizi mikro dengan kejadian stunting baik daerah gambut maupun daerah aliran sungai.

b. Hubungan antara Tb ibu dengan kejadian stunting Berdasarkan Tabel 3 variabel TB ibu didapat bahwa pada daerah gambut subjek penelitian lebih banyak Tinggi Badan (TB) ibu $>150 \mathrm{~cm}$, mengalamai status gizi normal $68,3 \%$. Begitu juga pada daerah aliran sungai subjek penelitian lebih banyak Tinggi Badan (TB) ibu $>150 \mathrm{~cm}$, mengalamai status gizi normal 7I,I\%. Hasil uji chi square menunjukan bahwa tidak ada hubungan yang signifikan $(p=<0,05)$ antara Tinggi Badan (TB) ibu $>150 \mathrm{~cm}$ dengan kejadian stunting baik daerah gambut maupun daerah aliran sungai.

\section{Analisis Multivariat}

Table 4. Hasil Analisis Hubungan status Zat gizi mikro dan Tb ibu dengan Kejadian Stunting

\begin{tabular}{|c|c|c|c|c|c|c|c|c|}
\hline \multirow{2}{*}{ Variabel } & \multicolumn{4}{|c|}{$\begin{array}{l}\text { Gambut } \\
\mathrm{Cl}(95 \%)\end{array}$} & \multicolumn{4}{|c|}{$\begin{array}{l}\text { Bantaran Sungai } \\
\mathrm{Cl}(95 \%)\end{array}$} \\
\hline & OR & $\begin{array}{l}\text { Batas } \\
\text { Bawah }\end{array}$ & $\begin{array}{l}\text { Batas } \\
\text { Atas }\end{array}$ & $p$ & OR & $\begin{array}{l}\text { Batas } \\
\text { Atas }\end{array}$ & $\begin{array}{l}\text { Batas } \\
\text { Bawah }\end{array}$ & $p$ \\
\hline Zat Gizi Mikro & 0,24 & 0,06 & 0,93 & 0,039 & 5.80 & $0,5 I 5$ & 65.49 & 0,155 \\
\hline TB lbu & $\mathrm{I}, 70$ & 0,30 & 9,60 & 0,545 & 3.33 & 0,168 & 66.26 & 0,430 \\
\hline Constant & 0,39 & & & $0,4 \mid 4$ & 1.14 & & & 0.937 \\
\hline
\end{tabular}

Berdasarkan hasil analisi pada Tabel 5 diketahui bahwa ada hubungan signifikan $(p<0,05)$ antara zat gizi mikro dengan kejadian stunting di daerah gambut. Balita daerah gambut yang mengalami asupan zat gizi mikro rendah memiliki peluang 0,24 kali mengalami stunting. Berbeda dengan di daerah aliran sungai tidak ada hubungan signifikan $(p>0,05)$ antara zat gizi mikro dengan kejadian stunting. Balita daerah gambut yang mengalami asupan zat gizi mikro rendah memiliki peluang 5,8 kali mengalami stunting.

\section{PEMBAHASAN}

\section{a. Hubungan Zat gizi mikro dengan kejadian Stunting}

Zat gizi mikro dalam penelitian ini adalah fero, zinc, iodium dan vitamin A. Hasil analisi menunjukan terdapat hubungan yang signifikan antara zat gizi mikro dengan kejadian stunting di daerah gambut. Berbeda dengan di daerah bantaran sungai tidak ada hubungan signifikan antara zat gizi mikro dengan kejadian stunting. Sejalan dengan penelitian Sari et al (2016) didapat bahwa balita dengan asupan protein, kalsium, dan fosfor lebih rendah pada anak stunting dibandingkan pada anak tidak stunting usia 24-59 bulan di Kota Pontianak. Zat gizi mikro seperti vitamin $A$, zinc, zat besi dan iodin merupakan zat yang sangat penting untuk mencegah terjadinya stunting (Souganidis E, 20I2). Begitu juga zat gizi mikro lainnya seperti kalsium dan fosfor juga sangat penting perannya dalam pertumbuhan linier anak (van Stuijvenberg et al., 2015)

\section{b. Hubungan status Tinggi Badan Ibu dengan kejadian Stunting.}

Faktor genetik merupakan modal dasar dalam mencapai hasil akhir proses tumbuh kembang. Pesan genetik yang 
diturunkan oleh orang tua dan tersimpan dalam deocsiribose nucleic acid (DNA) akan menampilkan bentuk fisik dan potensi bayi. Sejalan dengan penelitian Ngaisyah (2016) menjelaskan bahwa tinggi badan ibu tidak ada hubungan yang bermakna dengan kejadian stunting. Tinggi Badan (TB) ibu dapat diwariskan kepada anak yang dilahirkan, karena ada faktor genetik ibu yang diturunkan.

Hasil analisis data penelitian didapat bahwa daerah gambut dan daerah bantaran sungai tidak ada hubungan signifikan antara tinggi badan ibu (TB) dengan kejadian stunting. Namun ibu balita yang TB $<150 \mathrm{~cm}$ berpeluang 1,7 kali pada daerah gambut dan 0,54 kali daerah bantaran sungai untuk melahirkan balita stunting. Penelitian Agustiningrum (2018) bahwa untuk tinggi badan ibu dengan kejadian stunting terdapat hubunga pada balita usia 24-59 bulan.

\section{KESIMPULAN}

I. Ada hubungan bermakna status zat gizi mikro dengan kejadian stunting daerah gambut, sedangkan daerah aloran sungai tidak berhubungan secara bermakna.

2. Tidak Ada hubungan bermakna status Tinggi Badan Ibu dengan kejadian stunting daerah gambut dan daerah aliran sungai

\section{UCAPAN TERIMA KASIH}

Terima kasih kami sampaikan kepada seluruh civitas akademika Poltekkes Kemenkes Pontianak yang telah membantu terlaksananya penelitian ini.

\section{REFERENSI}

I. Banerjee, K. and Dwivedi, L. K. (2020) 'Disparity in childhood stunting in India: Relative importance of community-level nutrition and sanitary practices', PLoS ONE, I5(9 September), PP. I-2I. doi: 10.1371/journal.pone.0238364.

2. Kementerian Kesehatan RI (2018) 'Laporan Riskesdas 2018', Laporan Nasional Riskesdas 2018, 53(9), Pp. I54-165. Available at: http://www.yankes.kemkes.go.id/assets/downloads/ PMK No. 57 Tahun 2013 tentang PTRM.pdf.

3. Fatimah, N. S. H. and Wirjatmadi, B. (2018) 'Tingkat Kecukupan Vitamin a, Seng Dan Zat Besi Serta Frekuensi Infeksi Pada Balita Stunting Dan Non Stunting', Media Gizi Indonesia, I3(2), pp. 168175. doi: 10.20473/mgi.v|3i2.168-175.

4. Kemenkes RI (2020) 'Standar Antropometri Anak', Standar Antropometri Anak, 2I(I), PP. I-9. doi: 10.1016/j.solener.2019.02.027.

5. Sulistyaningsih, D. A., Panunggal, B. and Murbawani, E. A. (2018) 'Status lodium Urine Dan Asupan lodium Pada Anak Stunting Usia 12-24 Bulan', Media Gizi Mikro Indonesia, 9(2), pp. 73-82. doi: 10.22435/mgmi.v9i2.1028.

6. Halim, L. A., Warouw, S. M. and Manoppo, J. I. C. (2018) 'Hubungan Faktor-Faktor Risiko dengan Stunting pada Anak Usia 3-5 Tahun di TK/PAUD Kecamatan Tumintang', I, pp. I-8.

7. Bening, S., Margawati, A. and Rosidi, A. (2017) 'Zinc deficiency as risk factor for stunting among children aged 2-5 years', Universa Medicina, 36(I), pp. II-I8. doi: 10.1805।/univmed.2017.v36.।I-I8.

8. Fikawati, S. (2009) 'Penyebab Keberhasilan dan Kegagalan Praktik Pemberian ASI Eksklusif', Kesmas: National Public Health Journal, 4(3), p. 120. doi: I0.21109/kesmas.v4i3.184.

9. Prendergast, A. J. and Humphrey, J. H. (20/4) 'The stunting syndrome in developing countries', Paediatrics and International Child Health, 34(4), PP. 250-265. doi: I0.I I79/20469055 I4Y.0000000I58.

10. Thagaard, I. N. et al. (20/8) 'The effect of obesity on early fetal growth and pregnancy duration: A cohort study', Journal of Maternal-Fetal and Neonatal Medicine. Informa UK Ltd., 3 I (22), pp. 294I-2946. doi: $10.1080 / 14767058.2017 .1359825$.

II. Bayu Dwi Welasasih, R. B. W. (20/2) 'Beberapa Faktor yang Berhubungan dengan Status Gizi Balita Stunting Author', The Indonesian Journal of Public Health, 8(3), Pp. 99-104. Available at: http://www.eskom.co.za/CustomerCare/TariffsAnd Charges/Documents/RSA Distribution Tariff Code Vers 6.pdf\%0Ahttp://www.nersa.org.za/. 
12. Souganidis E (20/2) 'Micronutrient Status in Vietnam', pp. 56-69.

13. Van Stuijvenberg, M. E. et al. (20I5) 'Low intake of calcium and vitamin $D$, but not zinc, iron or vitamin $A$, is associated with stunting in 2- to 5-year-old children', Nutrition. Elsevier Ltd, 3I(6), Pp. 84I846. doi: 10.1016/j.nut.2014.12.01।

14. Toliu, S. N. K. et al. (20I8) Hubungan Antara Tinggi Badan Orang Tua Dengan Kejadian Stunting Pada Anak Usia 24-59 Bulan di Kecamatan Pasan Kabupaten Minahasa Tenggara, Kesmas, Jurnal. 